J. Japan. Assoc, Min.

Petr, Econ, Geol.

70, 200-211, 1975

\title{
CHEMICAL COMPOSITION OF HORNBLENDES OF SOME RYOKE GRANITES, CENTRAL JAPAN
}

\author{
Satoshi Kanisawa \\ Department of Earth Science, College of Arts and Sciences, \\ Tohoku University, Sendai
}

\begin{abstract}
Hornblendes of some Ryoke granites were analysed chemically. Most of them are rich in iron and aluminum and some of them in alkalies. These characteristics are quite different from those of the Kitakami Mountains, Northeast Japan, which are relatively poor in iron and aluminum. Iron ores in the Ryoke granites are ilmenite and pyrrhotite (Tsusue \& Ishihara, 1974), whereas those in the Kitakami granites are generally magnetite.

These differences between granites from the two districts reflect the difference of oxygen fugacities during crystallization of granitic magmas. In the Ryoke Belt, oxygen fugacities were considerably lower than those in the Kitakami Mountains.
\end{abstract}

\section{INTRODUGTION}

The Ryoke belt in the Southwest Japan consists of typical andalustie-sillimantie type metamorphic rocks and large amounts of various granitic rocks which intruded into them.

Granitic rocks of the northeastern margin of the Ryoke belt are divided into several stages and some of them intruded into the late Cretaceous Nohi rhyolites, giving effects of contact metamorphism. Thus existence of the genetic connection between the late Mesozoic volcanism and some granitic rocks in the Southwest Japan is suggested from these facts (Yamada and Nakai, 1969; Yamada, 1971; Ryoke Research Group, 1972). However, data of rock forming minerals of these granitic rocks are very limited.

In this paper, chemistry of hornblendes of the Ryoke granitic rocks in central Japan which is situated within the northeastern part of the Ryoke Belt will be described in comparison with those of the
Kitakami Mountains in the Northeast Japan.

\section{BRIEF DESGRIPTION OF GRANITIC ROCKS}

The Ryoke Belt in Central Japan is composed of metamorphic rocks of typical andalusite-sillimanite type (Miyashiro, 1961) which largely derived from pelitic and psammitic rocks accompanied by subordinate limestones and basic pyroclastics, and large amounts of granitic rocks. These granitic rocks are divided into following nine stages from the sequence of their intrusion and their rock facies (Ryoke Research Group, 1972).

1st stage Kamihara-Hiji quartz diorites

2nd stage Tenryukyo-Minakata granodiorites

3rd stage Kiyosaki-Katsuma quartz diorites

4th stage Mitsuhashi-Ikuta granodiorites

5th stage Inagawa granodiorites

6th stage Ichida granites 


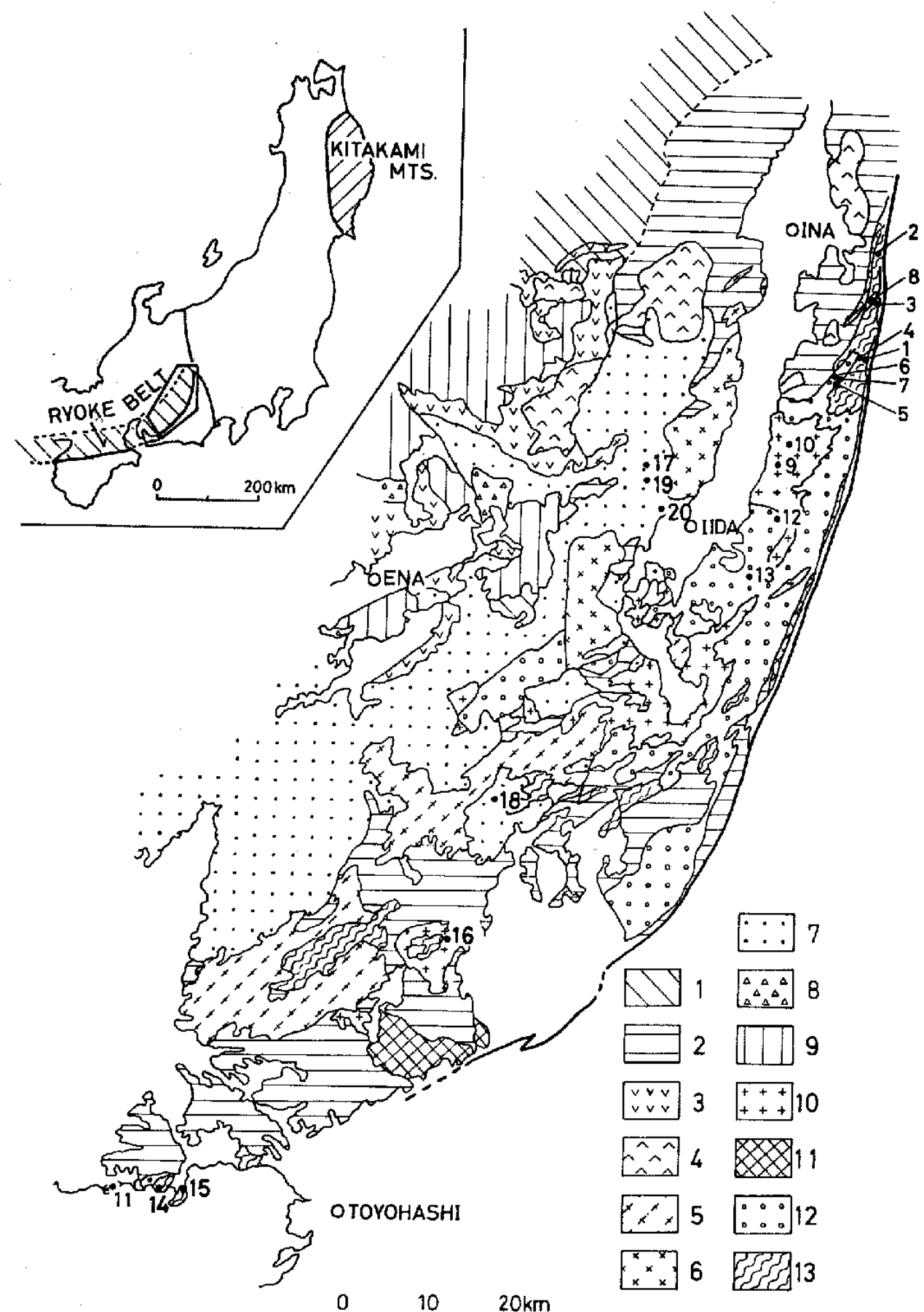

Fig. 1. Simplified geological map of the Ryoke Belt in Central Japan (originally compiled by the Ryoke Research Group, 1972) and sampling locations studied.

Legned 1: Unmetamorphosed Paleozoic Formations, 2: Ryoke metamorphic rocks, 3: NaegiAgematsu granites, 4: Takato-Kisokoma granodiorites, 5: Busetsu-Kadoshima granites, 6: Ichida granites, 7: Inagawa granodiorites, 8: Granite porphyry, 9: Nohi rhyolites, 10: Mitsuhashi-Ikuta granodiorites, 11: Metadiabase, 12: Tenryukyo-Minakata granodiorites, 13: Hiji-Kamihara quartz diorites. 
7th stage Busetsu-Kadoshima granites

8th stage Takato-Kisokoma granodiorites

9th stage Naegi-Agematsu granites

The eruption of the Nohi rhyolites of the late Cretaceous had been completed before the emplacement of the 5th stage Inagawa granodiorites (Yamada \& Nakai, 1969). Thus, the granites of the 1st to 4th stages are called "the Ryoke granites in strict sense" (Yamada and Nakai, 1969) or "the Older Ryoke granites" (Yamada, 1971) and those after the 5th stage are "the Post-Nohi granites" (Yamada and Nakai, $1969)$ or "the Younger Ryoke granites" (Yamada, 1971). The Older Ryoke granites are composed of various rock facies ranging from granodiorite to quartz diorite and are characterized by strong gneissosity which is harmonic commonly with the general trend of the Ryoke Belt. Their distribution is limited mostly within the higher grade zone of the Ryoke metamorphism. On the contrary, the Younger Ryoke granites are widely developed over the whole area of the Ryoke Belt and are extended into the non-metamorphosed Paleozoic terrain. They are discordant to the general trend of the Ryoke metamorphic rocks as well as those of the older Ryoke granites, and they affected distinct contact metamorphism to the surrounding racks.

The compiled and simplified geologic map of the Ryoke Belt in the central Japan and sampling locations are shown in Fig. 1.

\section{OgGurRenGes of Hornblendes}

Hornblendes of granitic rocks of the present study are all associated with biotites and potash feldsaprs. Plagioclases are mostly polysynthetically twinned and show homogeneous composition or very weak zonal structure having narrow compositional range. Hormblendes are hypidiomorphic granular in all granites. In the Hiji quartz diorites, hornblendes show bluish green Z axial colour, however, those in the other granites are commonly green to brownish green in $\mathrm{Z}$-axial colour. Twinning on (100) is common. Hornblendes in the Tenryukyo granites are sometimes associated with cummingtonite. Amounts of opaque minerals are very scarce in all of the Ryoke granites and most of them are ilmenite or pyrrhotite. Sphene, allanite, zircon and apatite are common accessories in all granites.

\section{Chemical Composition of Horn- BLENDES}

Twenty hornblendes of various granites in the district were separated by means of Franz Isodynamic Separator and heavy liquid and were chemically analysed. Four specimens were collected from the Hiji quartz diorites, four from the Minakata granodiorites, two from the Ikuta granodiorites, three from the Tenryukyo granodiorites, one from the Kamihara quartz diorites and two from the Mitsuhashi granodiorites which belong to the Older Ryoke granites and four from the Inagawa granodionites of the Younger Ryoke granites.

The hornblende analyses were done with a combination of gravimetry and atomic absorption spectrophotometry using a HITACHI model 508 atomic absorption spectrophotometer. The analytical results are presented in Table 1 , in the order of decreasing $m g\left(=\mathrm{Mg} / \mathrm{Mg}+\mathrm{Fe}^{+2}+\mathrm{Fe}^{+3}+\mathrm{Mn}\right)$ in each granitic unit.

It is clear from the results that all hornblendes of granites of the district are comparatively rich in $\mathrm{Fe}$ and $\mathrm{Al}$ and poor 
Table 1. Chemical analyses of hornblendes from the Ryoke granitic rocks.

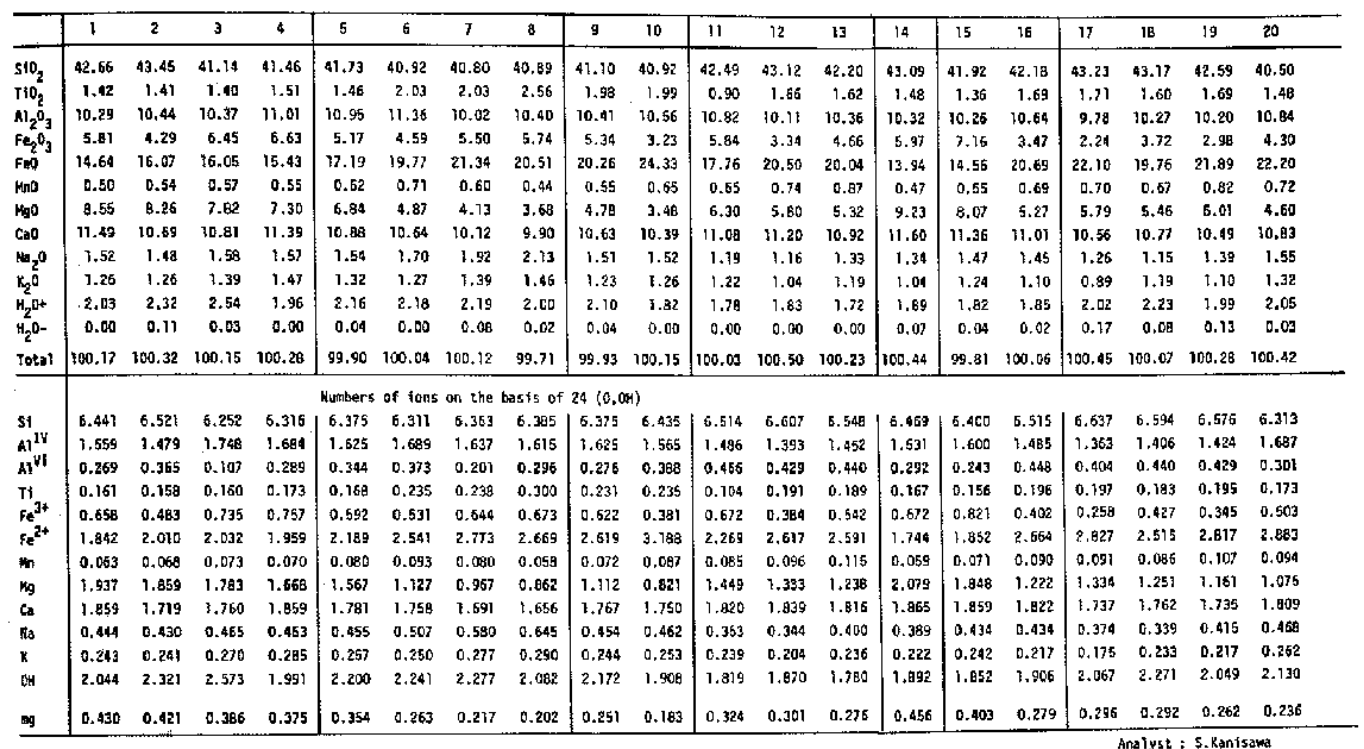

Hiji quartz diorites

1. Specimen No. $71081407(\mathrm{HJ}-3)$, Hornblende-biotite-quartz diorite.

2. 71081401 (HJ-1), Hornblende-biotite-quartz diorite.

3. $71081405(\mathbf{H J}-2)$, Biotite-hornblende-quartz diorite.

4. $71081408(\mathrm{HJ}-4)$, Hornblende-biotite-quartz diorite.

Minakata granodiorites

5. 71081411 (MN-3), Hornblende-biotite-quartz diorite.

6. 71081412 (MN-4), Hornblende-biotite granodiorite.

7. 71081410 (MN-2), Hornblende-biotite granodiorite.

8. 71081404 (MN-1), Hornblende-biotite granodiorite.

Ikuta granodiorites

9. 73081205, Hornblende-biotite granodiorite.

10. 71082801, Hornblende-biotite granodiorite.

Tenryukyo granodiorites.

11. $72 \mathrm{~N}-26$ (Collected by H. Kanaya), Curnmingtonite-hornblende-biotite-quartz diorite.

12. 73081201, Cummingtonite-hornblende-biotite granodiorite.

13. 73081204, Hornblende-biotite granodiorite.

Kamihara quartz diorites.

14. $72 \mathrm{~N}-25$ (Collected by H. Kanaya), Biotite-hornblende-quartz diorite.

Mitsuhashi granodiorite.

15. $72 \mathrm{~N}-22$ (Collected by $\mathrm{H}$. Kanaya), Biotite-hornblende granodiorite.

16. $72 \mathrm{~N}-42$ (Collected by $\mathrm{H}$. Kanaya), Hornblende-biotite-quartz diorite.

Inagawa granodiorites.

17. 73081002, Hornblende-biotite granodiorite.

18. $72 \mathrm{~N}-65$ (Collected by $\mathrm{H}$. Kanaya), Hornblende-biotite-quartz diorite.

19. 73081003, Hornblende-biotite-quartz diorite.

20. 73081006, Hornblende-biotite granodiorite.

Numbers are the same as those in Fig. 1.

in Mg. Hornblendes of the Hiji and Minakata granites are slightly rich in $\mathrm{Fe}^{+3}$ and $\mathrm{Na}+\mathrm{K}$, thus belong to magnesian has- tingsitic hornblende and hastingsite according to Leake's classification (1968). Hornblendes of other granites mostly belong to 
ferro-hormblende. Hornblendes of the Minakata granodiorites are rich in $\mathrm{Ti}$. Those of the Inagawa granodiorites are slightly poor in $\mathrm{Fe}^{+3}$ and $\mathrm{Na}+\mathrm{K}$.

The difference of chemical characteristics of granitic hornblendes among the individual granitic units even in the Younger and the Older granites in the Ryoke Belt are not so significant. However, the differences between granitic hornblendes from the Ryoke belt and the Kitakami Mountains are very conspicuous as shown in the following section.

Comparison of Ghemical GharacTERISTIGS OF HORNBLENDES FROM THE ROGKS OF THE RYOKe BELT AND The Kitakami Mountains

There are significant characters of hornblendes in the two districts that those of the Ryoke granites are generally rich in $\mathrm{Al}$ and $\mathrm{Fe}$, whereas those of the Kitakami Mountains are poor in $\mathrm{Al}$ and rich in $\mathrm{Mg}$. Data of hornblendes of the Kitakami Mountains are quoted from Kanisawa (1969, 1972, 1974 and unpublished data) and Kato (1972 and 1973).

Hornblendes of the Ryoke granites have large amounts of $\mathrm{Al}^{\mathrm{VI}}$ and $\mathrm{Al}^{\mathrm{IV}}$, but those of the Kitakami Mountains have frequently no $\mathrm{Al}^{\mathrm{VI}}$. $\mathrm{Al}^{\mathrm{IV}}$ replacing $\mathrm{Si}$ is nearly 1.5 in the Ryoke hornblendes, while that is approximately 1 in the Kitakami hornblendes. In the $\mathrm{Al}^{\mathrm{TV}}-(\mathrm{Na}+\mathrm{K})$ and $\mathrm{Al}^{\mathrm{Iv}}$ $\left(\mathrm{Al}^{\mathrm{VI}}+\mathrm{Fe}^{+3}+\mathrm{Ti}\right.$ ) diagrams (Deer et al., $1963)$, it is evident that hornblendes of the Ryoke granites are rich in $\mathrm{Na}+\mathrm{K}, \mathrm{Al}^{\mathrm{IV}}$ and $\mathrm{Al}^{\mathrm{VI}}+\mathrm{Fe}^{+3}+\mathrm{Ti}$ than those of the Kitakami Mountains (Fig. 2). Niggli's $m g$ value of the Ryoke hornblendes ranges from 0.18 to 0.46 , whereas that of the Kitakami hornblendes is larger than 0.43 . In the $\left(\mathrm{Al}^{\mathrm{VI}}+\right.$
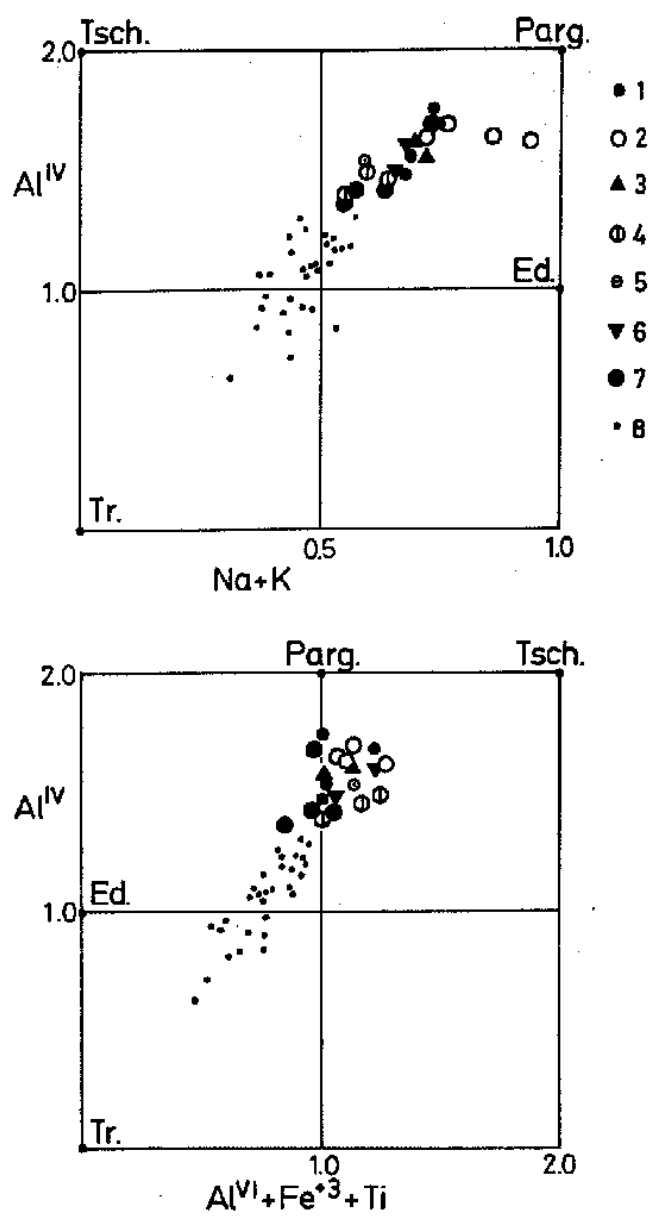

Fig. 2. $\mathrm{Al}^{\mathrm{IV}}-(\mathrm{Na}+\mathrm{K})$ and $\left(\mathrm{Al}^{\mathrm{V}}+\mathrm{Fe}^{+8}+\mathrm{Ti}\right)$ diagrams of hornblendes from the Ryoke and the Kitakami granites. 1: Hiji quartz diorites, 2: Minakata granodiorites, 3: Ikuta granodiorites, 4: Tenryukyo granodiorites, 5 : Kamihara quartz diorites, 6: Mitsuhashi granodiorites, 7; Inagawa granodiorites, 8: Granites of the Kitakami Mountains. The same symbols are used in all figures.

$\left.\mathrm{Fe}^{+8}+\mathrm{Ti}\right)-\left(\mathrm{Fe}^{+2}+\mathrm{Mn}\right)-\mathrm{Mg}$ diagram (Fig. 3), which represents the octahedrally coordinated cation ratios, $\mathrm{Fe}^{+2} / \mathrm{Mg}$ ratio of the Ryoke hornblendes is larger than 0.5, whereas that of the Kitakami hornblendes is smaller than 0.5. Further, it is clear from this diagram that the Ryoke hornblendes are 


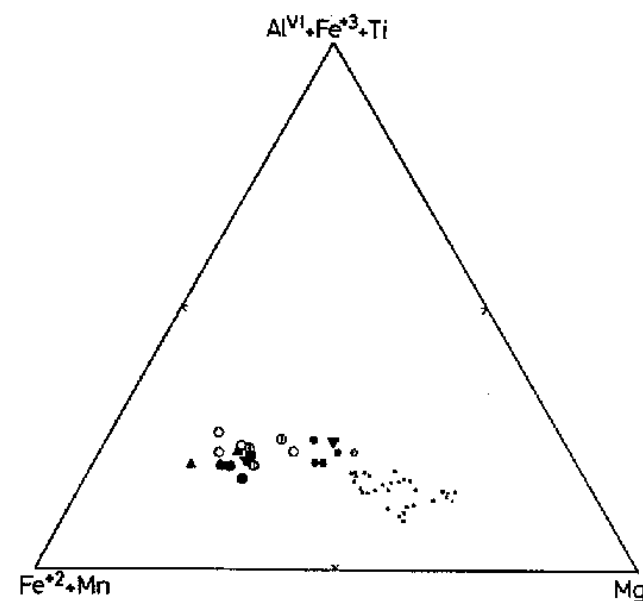

Fig. 3. ( $\left.\mathrm{Al}^{\mathrm{VI}}+\mathrm{Fe}^{+3}+\mathrm{Ti}\right)-\left(\mathrm{Fe}^{+2}+\mathrm{Mn}\right)-\mathrm{Mg}$ triangular diagram of hornblendes from the Ryoke and the Kitakami granites.

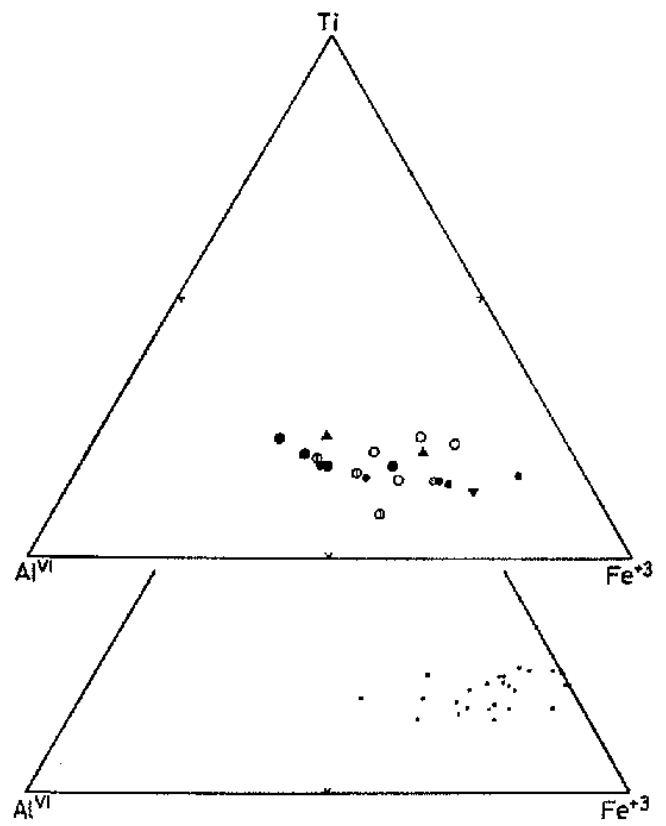

Fig. 4. $\mathrm{Al}^{\mathrm{rV}}-\mathrm{Ti}-\mathrm{Fe}^{+3}$ triangular diagrams of hornblendes from the Ryoke and the Kitakami granites.

richer in $\mathrm{Al}^{\mathrm{vi}}+\mathrm{Fe}^{+3}+\mathrm{Ti}$ than the Kitakami hornblendes. In the diagram of $\mathrm{Al}^{\mathrm{VL}}-\mathrm{Fe}^{+3}$ -Ti (Fig. 4), hornblendes of the Ryoke granites are slightly rich in $\mathrm{Al}^{\mathrm{vI}} . \mathrm{Ti} \rightleftharpoons$ $\mathrm{Al}^{\mathrm{VI}}+\mathrm{Fe}^{+3}$ substitution is nearly constant in hornblendes of the both districts. $\mathrm{Fe}^{+3}$

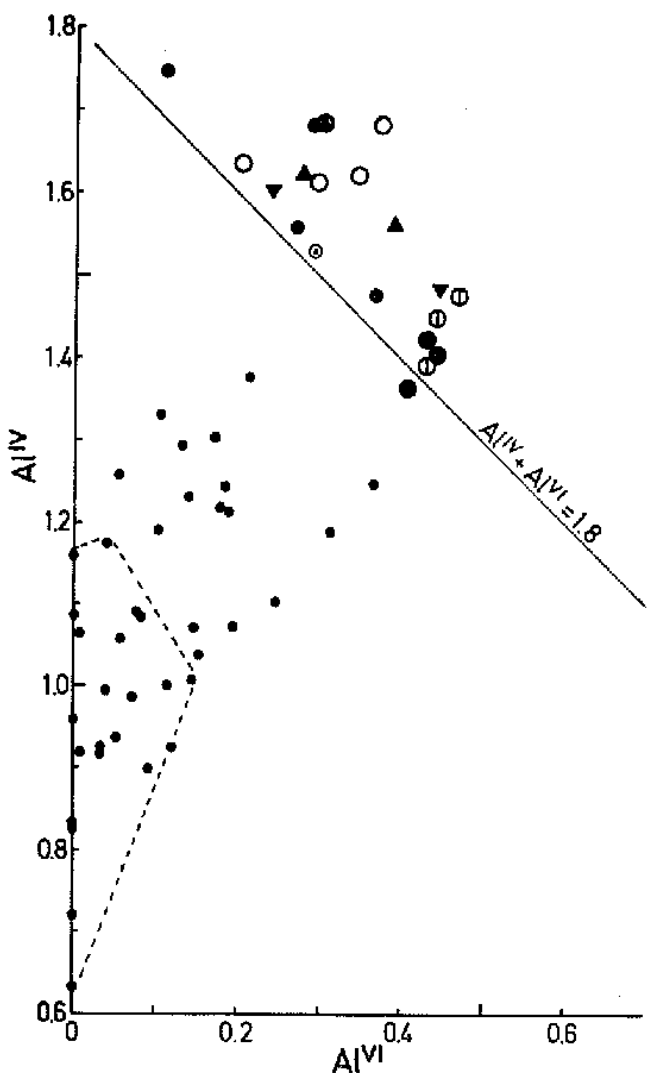

Fig. 5. $\mathrm{Al}^{\mathrm{IV}}-\mathrm{Al}{ }^{\mathrm{VI}}$ relations of hornblendes from the Ryoke and the Kitakami granites. Hornblendes from granites closely associated with the Lower Cretaceous volcanic rocks in the Kitakami Mountains (Kanisawa, 1974) fall within the area surrounded by dotted line.

$/ \mathrm{Fe}^{+2}$ ratios are generally lower in Ryoke hormblendes than those of the Kitakami Mountains, except those of the Hiji quartz diorites. $\mathrm{K}_{2} \mathrm{O}$ is rich in the Ryoke homblendes.

Hornblendes of the Ryoke granites are commonly high in $\mathrm{Al}$, especially in $\mathrm{Al}^{\mathrm{VI}}$. Consequently, the Ryoke hornblendes are plotted in the area of $\mathrm{Al}^{\mathrm{IV}}+\mathrm{Al}^{\mathrm{YI}}>1.8$ in the $\mathrm{Al}^{\mathrm{IV}}-\mathrm{Al}^{\mathrm{vI}}$ diagram (Fig. 5). However, hornblendes from granitic rocks closely associated with the Lower Cretaceous volcanic rocks in the Kitakami Mountains 
(Kanisawa, 1974) are plotted in a narrow area poor in both $\mathrm{Al}^{\mathrm{IV}}$ and $\mathrm{Al}^{\mathrm{VI}}$ in the diagram. Hornblendes of the Tono, Hitokabe, Kesengawa and Kinkasan granitic masses all of which represent large bodies in the Kitakami Mountains, are plotted between the area of hornblendes from the Ryoke granites and the area of those from granites associated with the Cretaceous volcanic rocks in the Kitakami Mountains. $\mathrm{Al}^{\mathrm{IV}}+\mathrm{Al}^{\mathrm{VI}}$ values of all hornblendes from the Kitakami Mountains do not exceed 1.6.

\section{Chemical Charagteristigs of ANALYSED Hornblende-BEARING Rocks}

Chemical analyses of the Ryoke granitic rocks containing analysed homblendes are given in Table 2, in the same order as the analysed hornblendes. From these data, granites of the district show the trend of typical calc-alkaline rock series. Most of the Ryoke granites have higher $\mathrm{Al}_{3} \mathrm{O}_{8}$ content, thus normative corundum is calculated from the analytical data. Variation diagrams of oxides versus differentiation index were drawn as shown in Fig. 6. It is clear from the diagrams that the chemical variation of rocks of the present study, especially $\mathrm{CaO}, \mathrm{SiO}_{2}$, total $\mathrm{FeO}$ and $\mathrm{TiO}_{2}$ is nearly equal to the trend of the average Japanese granitic rocks (Aramaki et al., 1972). However, $\mathrm{Al}_{2} \mathrm{O}_{3}$, $\mathrm{FeO}$ and $\mathrm{Na}_{2} \mathrm{O}$ contents are higher and $\mathrm{MgO}$ and $\mathrm{Fe}_{2} \mathrm{O}_{3}$ are slightly lower than those of average Japanese granitic rocks. There is no marked difference in variation of all components throughout all granitic units.

In comparison with those in the Kitakami Mountains, the Ryoke granites are rich in $\mathrm{Al}_{2} \mathrm{O}_{3}$ and poor in $\mathrm{MgO}$. Oxidation ratio (mol. $2 \mathrm{Fe}_{2} \mathrm{O}_{3} / 2 \mathrm{Fe}_{2} \mathrm{O}_{3}+\mathrm{FeO}$, Chinner, 1960) of granites in the Ryoke belt is commonly smaller than those of the Kitakami Mountains, and the relation between

Table 2. Chemical analyses of rocks containing analysed hornblendes.

\begin{tabular}{|c|c|c|c|c|c|c|c|c|c|c|c|c|c|c|c|c|c|c|c|c|}
\hline & 1 & 2 & 3 & 4 & 5 & 6 & 7 & 8 & 9 & 10 & 11 & 12 & 13 & 14 & 15 & 15 & 17 & 18 & 19 & 20 \\
\hline $51 O_{2}$ & 62,42 & 62.86 & 64.13 & 59.95 & 66.98 & 68.00 & 69.96 & 69.73 & 71.36 & 66.18 & 64.48 & 65.20 & 68.50 & 57.26 & 67.68 & 65.02 & 68.68 & 62.32 & 67.90 & 67.76 \\
\hline $\mathrm{TiO}_{2}^{2}$ & 0.73 & 0.78 & 0.68 & 0.87 & 0.60 & 0.32 & 0.94 & 0.38 & 0.43 & 0.46 & 0.68 & 0.61 & 0.49 & 0.95 & 0.51 & 0.62 & 0.50 & 0.91 & 0.53 & 0.57 \\
\hline $\mathrm{Al}_{2} \mathrm{~A}_{3}$ & 16.49 & 17.15 & 16.24 & 17.98 & 15.65 & 16.54 & 15.18 & 14.41 & 10.57 & 16.23 & 17.22 & 17.57 & 16.31 & 18.67 & 15.91 & 17.62 & 16.26 & 16.70 & 16.40 & 15.61 \\
\hline $\mathrm{Fe}^{2} \mathrm{O}^{3}$ & 1.58 & 0.43 & 1.02 & 1.53 & 1.15 & 0.91 & 0.80 & 1.03 & 0.67 & 0.49 & 0.89 & 0.52 & 0.50 & 1.73 & 1,00 & 0.73 & 0.33 & 0.97 & 0.51 & 0.59 \\
\hline $\mathrm{FeO}$ & 4.04 & 4.39 & 3.50 & 4.48 & 3.35 & 1.72 & 2.20 & 2.42 & 2.18 & 3.70 & 3.83 & 3.15 & 2.34 & 4.89 & 2.16 & 3.62 & 2.58 & 5.50 & 3.13 & 3.72 \\
\hline $\mathrm{MnO}$ & 0.11 & 0.10 & 0.09 & 0.12 & 0.08 & 0.05 & 0.04 & 0.05 & 0.06 & 0.09 & 0.09 & 0.08 & 0.06 & 0.13 & 0.07 & $0.0 \mathrm{a}$ & 0.05 & 0.12 & 0.09 & 0.10 \\
\hline $\mathrm{MgO}$ & 2.23 & 2.02 & 1.63 & 2.31 & 1.32 & 0.12 & 0.41 & 0.41 & 0.57 & 0.45 & 1.23 & 0.86 & 0.53 & 3.03 & 1.33 & 0.97 & 0.66 & 1.36 & 0.73 & 0.82 \\
\hline calo & 5.54 & 4.89 & 4.54 & 5.66 & 4.18 & 2.76 & 2.41 & 2.54 & 2.35 & 3.23 & 4.60 & 3.67 & 2.90 & 6.72 & 3.73 & 4. 96 & 3.51 & 4.97 & 3.71 & 3.01 \\
\hline $\mathrm{Na}_{2} \mathrm{O}$ & 3.22 & 3.51 & 3.41 & 3.53 & 3.67 & 3.39 & 3.90 & 3.59 & 3.64 & 4.00 & 3.96 & $3 . \pi$ & 3.53 & 3.46 & 3.85 & 3.99 & 3.79 & 3.54 & 4.58 & 4.56 \\
\hline$K_{2}{ }^{6}$ & 1.51 & 2.00 & 2.44 & 1,91 & 1.70 & 4.92 & 3.59 & 3,81 & 3.47 & 3.05 & 2.27 & 4.05 & 4.27 & 1.70 & 2.89 & 1.55 & 2. 98 & 2.37 & 1.83 & 2.69 \\
\hline $\mathrm{H}_{2}^{2} \mathrm{OH}$ & 1.23 & 1.70 & 1.81 & 1.39 & 0.37 & 0.54 & $0.7 n$ & 1.43 & 0.53 & 0.54 & 0.62 & 0.68 & 0.49 & 1.45 & 0.60 & 0.75 & 0.63 & 1.04 & 0. $5 \mathrm{~B}$ & 0.55 \\
\hline $\mathrm{H}_{2}^{\mathrm{O}}$ & 0.08 & 0.07 & 0.08 & 0.09 & 0.05 & 0.05 & 0.04 & 0.07 & 0.08 & 0.04 & 0.03 & 0.04 & 0.00 & 0.10 & 0.05 & 0.04 & 0.04 & 0.09 & 0.04 & 0.02 \\
\hline$P_{2^{0}}^{c}$ & 0.18 & 0.21 & 0.17 & 0.22 & 0.15 & 0.08 & 0.13 & 0.12 & 0.10 & 0.12 & 0.18 & 0.13 & 0.12 & n.d. & n.d. & n.d. & 0.11 & 0.25 & 0.14 & 0.13 \\
\hline Tota! & 99.46 & 100.10 & 99.74 & 99.84 & 99.65 & 99.79 & 99.71 & 99.99 & 100.03 & 99.58 & 100.13 & 100.44 & 100.13 & 100.10 & 100,28 & 99.85 & 100.12 & 99.64 & 100.17 & 100.16 \\
\hline 0 & 20.68 & 18. 94 & 21.37 & 34.86 & 26.68 & 22.35 & 26,83 & 27.17 & 30.05 & 23.87 & 19.19 & 17.14 & 23.37 & 9.54 & 23.14 & 21.62 & 25.39 & 18.02 & 23.50 & 21.14 \\
\hline c. & - & 0.83 & 0.11 & 0.30 & 0.52 & 0.92 & 0.79 & 0.07 & 0.73 & 0.72 & 0.36 & 0.70 & 0.86 & - & - & 0.33 & 0.06 & 0.77 & 0.45 & 0.04 \\
\hline for & 9.51 & 11.84 & 14.46 & 11.29 & 10.06 & 29.08 & 21.24 & 22.52 & 20.52 & 18.01 & 13.40 & 23.96 & 25.24 & 10.06 & 17.07 & 9.17 & 17.63 & 14.01 & 10.84 & 15.90 \\
\hline$F\{a b$ & 27.20 & 29.66 & 28.82 & 29.82 & 31.02 & 2B. 56 & 32.96 & 30.34 & 30.76 & 33.80 & 33.48 & 31.86 & 29.82 & 29.24 & 32.54 & 33.75 & 32.02 & 29.92 & 38.72 & 38.51 \\
\hline 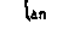 & 25.77 & 22.82 & 21.43 & 26.72 & 19.74 & 13.15 & 11.12 & 11.90 & 11.04 & 15.32 & 21,63 & 17.10 & 13.68 & 30.33 & 17.57 & 24.63 & 16.71 & 20.54 & 17.51 & 14.12 \\
\hline poo & 0.22 & - & - & - & - & - & - & - & - & - & - & - & . & 1.26 & 0.39 & - & - & - & - & - \\
\hline 01$\}$ en & 0.11 & - & - & - & - & - & - & - & - & - & - & - & - & 0.67 & 0.20 & - & - & - & - & - \\
\hline lfs & 0.11 & - & $=$ & - & - & - & - & - & - & - & - & " & - & 0.55 & 0.10 & - & - & - & $=$ & - \\
\hline$f^{e n}$ & 5.47 & 5.05 & 4,08 & $5.2 B$ & 3.30 & 1.05 & 1.03 & 1.03 & 1.43 & 1.15 & $3.0 \mathrm{~B}$ & 2.15 & 1.58 & 6.91 & 3.13 & 2.16 & 1.65 & 3.40 & 1.83 & 2.05 \\
\hline$\left.{ }^{k y}\right\}_{f 5}$ & 4,99 & 6.59 & 4.62 & 5.73 & d. 34 & 1.97 & 2.89 & 3.05 & 2.84 & 4.65 & 5. 33 & 4.51 & 3.19 & 5.65 & 2.79 & 5.15 & $3 . n$ & 8.28 & 4,62 & 5.56 \\
\hline Mt & 2.30 & 0.63 & 1.48 & 2.23 & 1.67 & 1.32 & 1,16 & I. $4 \mathrm{~B}$ & 0.97 & 0.72 & 7.30 & 0.77 & 0.72 & 2.51 & 3.46 & 1.07 & 0,49 & 1.25 & 0.74 & 0.86 \\
\hline$\pi$ & 1.38 & 3.49 & 1.29 & $\$ .66$ & 1.14 & 0.61 & 0.65 & 0.33 & 0.82 & 0.89 & 1.29 & 1.12 & 0,91 & 1.81 & 0.97 & 1.19 & 0.96 & 3.73 & 1.06 & 1.00 \\
\hline Ap & 0.14 & 0.50 & 0.40 & 0.50 & 0.37 & 0.20 & 0.30 & 0,27 & 0.24 & 0.27 & 0.44 & 0.40 & 0.27 & - & - & - & 0.27 & 0.60 & 0.34 & 0.30 \\
\hline mig & 0.419 & 0.427 & 0,394 & 0.389 & 0.347 & 0.226 & 0.200 & 0.179 & 0.266 & 0.186 & 0.319 & 0.295 & 0.286 & 0.454 & 0.411 & 0.265 & 0.288 & 0.274 & 0.263 & 0.253 \\
\hline of & 57.39 & 60.44 & 64,45 & 55.97 & 67.76 & 79.99 & BI.03 & 80.03 & 01.33 & 75.68 & 65.07 & 72.95 & 78.43 & 48.84 & 12.75 & 64.54 & 75.04 & 61.95 & 73.06 & 75.55 \\
\hline
\end{tabular}



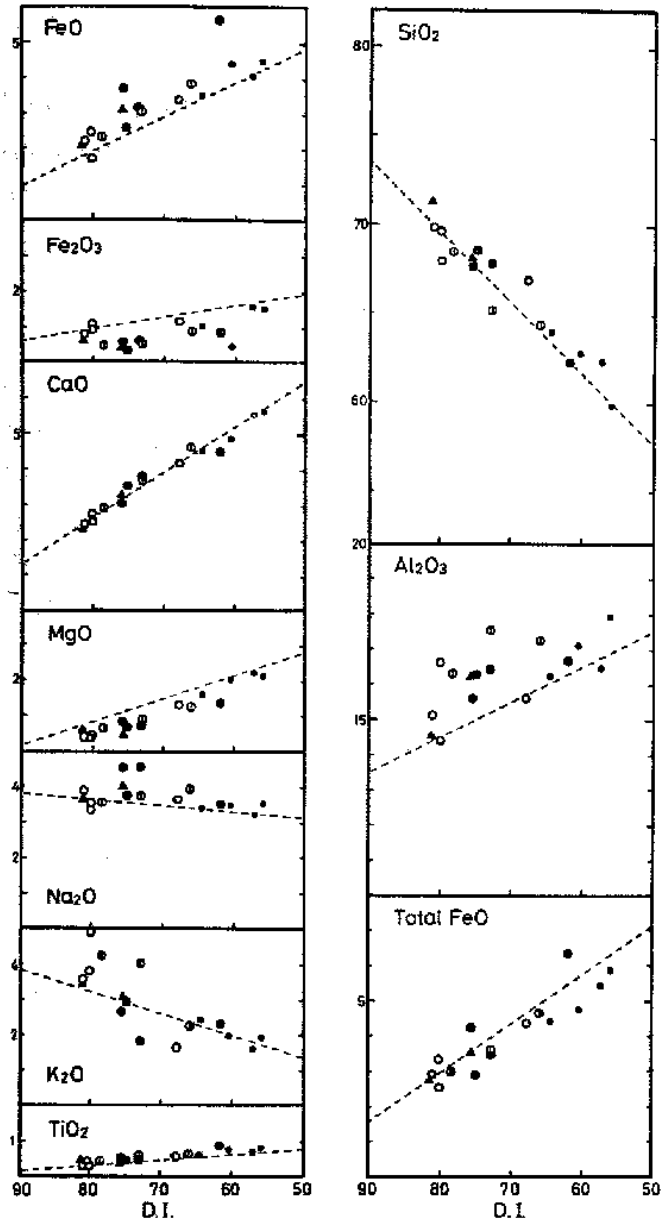

Fig. 6. Variation diagram of the analysed hornblende bearing granites, Dotted lines indicate the trend of the average Japanese granites by Aramaki et al. (1972).

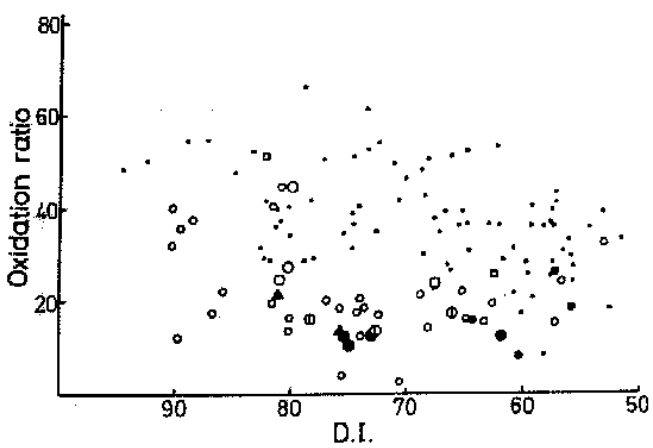

Fig. 7. Relation between differentiation index and oxidation ratios of granites in the Ryoke Belt and the Kitakami Mountains. Small

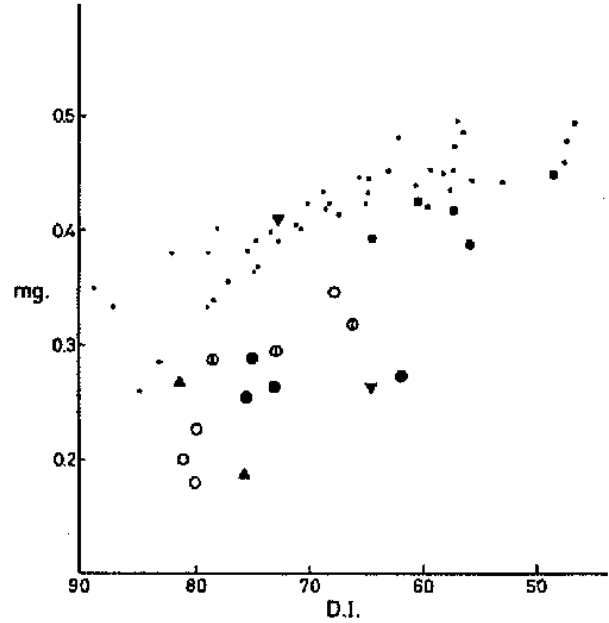

Fig. 8. Relation between differentiation index and $m g$ of hornblende bearing granites.

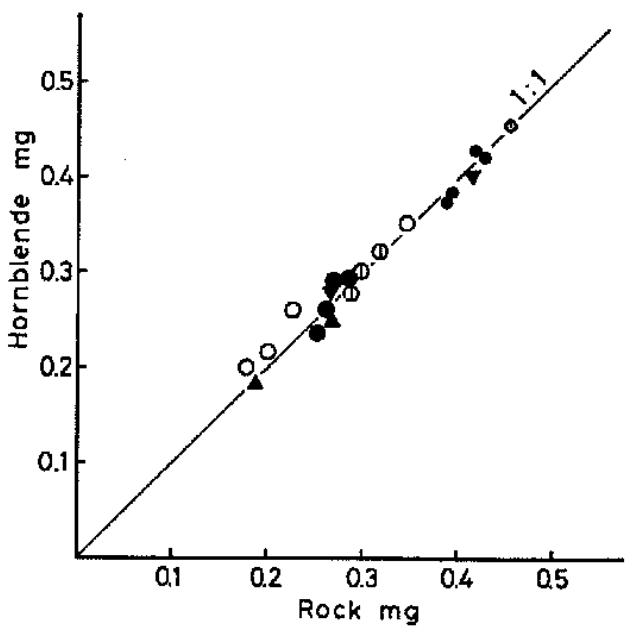

Fig. 9. Relation between rock $m g$ and hornblende $m g$ of the Ryoke granites.

the oxidation ratio and differentiation index are shown as in Fig. 7. This fact reflects that the granitic rocks of the Kitakami Mountains contain large amounts of magnetite, whereas those of the Ryoke Belt are none in it. Iron ores of the Ryoke granites are mainly pyrrhotite and ilmenite. The Ryoke granites have low $\mathrm{Mg} / \mathrm{Fe}$ ratio,

open circles represent the Ryoke granites from various literatures. 
thus their mg values are always smaller than those of the Kitakami Mountains as shown in Fig. 8.

The relationship between $m g$ of hornblendes and their host rocks is shown in Fig. 9. It is clear that $\mathrm{mg}$ values of hornblendes range from 0.456 to 0.183 and they depends almost directly on the values of their host rocks. This fact reflects that Feoxides in the Ryoke granites are very small in amount and. $\mathrm{Fe}$ and $\mathrm{Mg}$ were equally distributed into coexisting biotites and hornblendes.

Biotites in the Ryoke granites of present study are also richer in $\mathrm{Fe}$ and $\mathrm{Al}$ than those of the Kitakami, and their $m g$ values also depend on their host rocks (Kanisawa, unpublished data).

\section{Genetic Consideration of Horn- BLENDES}

Homblendes of the Ryoke granites in the Central Japan are commonly rich in $\mathrm{Fe}$ and $\mathrm{Al}$, and some of them belong to ferrohastingsite. Ferrohastingsitic homblendes are well established in many syenitic rocks and potash-rich granites, e.g. in the rocks of the Diana-Stark Complex, northwest Adirondacks, and in the younger granitic rocks of the same area (Buddington and Leonard, 1953), and the younger granites of Nigeria (Borley, 1963). However, wide distribution of these iron-rich hornblendes in typical calc-alkaline granodiorites are rather uncommon.

Hornblendes of granitic rocks in the Kitakami Mountains are different from those of the Ryoke granites and have moderate amounts of $\mathrm{Fe}$ and $\mathrm{Mg}$, and slightly lower amount of $\mathrm{Al}$. Hornblendes of the Kitakami Mountains are similar in composition to those in the Sierra Nevada granodiorites (Dodge et al., 1968; Hietanen,
1971).

The Ryoke hornblendes are not associated with magnetite but ilmenite and pyrrhotite. Recently, Kanaya and Ishihara (1973) have pointed out that magnetic susceptibility of the granitic rocks in Japan has different values for rocks of each geologic structural unit and geologic time, and averages of the $\chi$-values of granodiorites of the major granitic units are the highest in the rocks of the Kitakami Mountains and the lowest in those of the Ryoke Belt in Japan, and that the values increase from the Ryoke Belt to the Japan Sea side, showing regional variation with zonal arrangement in the Southwest Japan. Further, Tsusue and Ishihara (1974) have clarified that contents of opaque minerals of granitic rocks in the Ryoke Belt are generally low, comprising ilmenite, which contains 4-19 mol. \% of pyrophanite and $4 \mathrm{~mol} \%$ of hematite end members, pyrrhotite and marcasite inverted from pyrrhotite and rarely chalcopyrite. They have also suggested that mafic silicates rich in $\mathrm{Fe}^{+2}$ crystallized first, followed by the crystallization of ilmenite and that simultaneous crystallization of both minerals continued.

From the facts mentioned above, it is suggested that oxygen fugacities during crystallization process of the Ryoke granitic magma were fairly lower than those of the Kitakami granites. When $f_{0_{1}}$ is high during crystallization of magma, large amounts of $\mathrm{Fe}$ enter into magnetite, making $\mathrm{Fe} / \mathrm{Mg}$ ratios in ferromagnesian silicates lower, while, low oxygen fugacities are favourable to form Fe-rich ferromagnesian silicates (Osborn, 1962) such as the Ryoke hornblendes. Since granitic rocks in the Kitakami Mountains are rich in magnetite and have hornblendes and biotites both poor in $\mathrm{Fe}$, it is evident that they may have 
been formed at higher oxygen fugacities than those of the Ryoke Belt.

It may be true to some extent that elevated pressure is favourable to increase aluminum content in hornblendes, especially the maximum amount of Alvi (Leake, 1965; Holloway and Burnham, 1972).

The Ryoke hornblendes are richer in $\mathrm{Al}^{\mathrm{VI}}$ and $\mathrm{Al}^{\mathrm{IV}}$ than those of Kitakami. Especially, hornblendes of granitic rocks associated with the volcanic rocks in the Kitakami Mountains, which represent shallow intrusives are poor in $\mathrm{Al}^{\mathrm{IV}}$ and $\mathrm{Al}^{\mathrm{VI}}$. Thus, the Ryoke hornblendes may have crystallized out at deeper position than those of Kitakami. However, the amount of $\mathrm{Al}^{\mathrm{VI}}$ in hornblende is not directly proportional to the pressure during crystallization, because the composition of magma is no less important. $\mathrm{Al}_{2} \mathrm{O}_{3}$ content of granitic rocks in the Ryoke Belt are higher than those of Kitakami. Thus the host rock chemistry may also be important factor for deciding $\mathrm{Al}$ content of hornblendes.

Dodge (1973) has concluded from his studies of the Sierra Nevada granites that differences in oxygen fugacities in granitic rocks probably resulted from different water contents of source materials from which the granitic magmas were formed. There exist many differences in the geologic history and igneous activity between the Southwest and the Northeast Japan. Therefore, it is expected that the different processes of the generation and crystallization of granitic magmas may have been reflected on the chemistry of the hornblendes crystallized out from these magmas.

\section{GoNCLUSION}

Twenty hornblendes from various Ryoke granites, Central Japan were analysed. They are characteristically rich in iron and aluminum, and their $m g$ values range from 0.46 to 0.18 and $\mathrm{Al}^{\mathrm{vI}}+$ $\mathrm{Al}^{1 v}$ exceed 1.8, whereas hornblendes of the Kitakami granites, Northeast Japan have higher $m g$ values (larger than 0.43) and lower $\mathrm{Al}^{\mathrm{VI}}+\mathrm{Al}^{\mathrm{IV}}$ content. Iron ores associated with hornblendes are ilmenite and pyrrhotite in the Ryoke granities, but magnetite in the Kitakami granites. Oxidation ratio of the Ryoke granites are generally lower than those of the Kitakami granites. These facts reflect the difference of oxygen fugacities during crystallization of magmas from the two districts. In the Ryoke Belt, oxygen fugacities during crystallization were fairly lower than those of the Kitakami Mountains. Aluminum contents of hornblendes may also reflect the bulk chemistry of granites, as well as the pressure during crystallization.

\section{ACKNOWLEDGEMENTS}

The author is greatly indebted to Professor Kenzo Yagi for critical reading of the manuscript and helpful suggestions. He is also greatful to Mr. Hiroshi Kanaya for providing the rock specimens of some Ryoke granites.

\section{REFERENCES}

Aramaki, S., Hirayama, K. and Nozawa, T. (1972), Chemical composition of Japanese granites, Part 2, Variation trends and average composition of 1200 analyses. Jour. Geol. Soc. Japan, 78, 39-49.

Borley, G.D. (1963). Amphiboles from the younger granites of Nigeria, Part I, Chemical classification. Mineral. Mag., 33, 358-376.

Buddington, A.F. and Leonard, B.F. (1953), 
Chemical mineralogy and petrology of hornblendes in Northwest Adirondack granitic rocks. Am. Mineral., 38, 891-902.

Chinner, G.A. (1960), Pelitic gneisses with varying ferrous/ferric ratios from Glen Cova, Angus, Scotland. Jour. Petrol., 1, 179-217.

Deer, W.A., Howie, R.A., and Zussman. J. (1963). Rock forming minerals, vol. 2; Chain silicates, Longmans, London.

Dodge, F.C.W. (1973), Viriation of ferrous-ferric ratios in the Central Sierra Nevada batholith. U.S.A., 24th I.G.C. Sect. 10. Geochemistry, I219.

Dodge, F.C.W., Papike, J.J. and Mays, R.E. (1968), Hornblendes from granitic rocks of the Central Sierra Nevada batholith, California. Jour, Petrol., 9, 378-410.

Hietanen, A. (1971), Distribution of elements in biotite-hornblende pairs and in an orthopyroxene-clinopyroxene pair from zoned plutons, Northern Sierra Nevada, California. Contr. Mineral. Petrol., 30, 161-176.

Holloway, J.R. and Burnham, W. (1972), Melting relations of basalt with equilibrium water pressure less than total pressure. Jour. Petrol., 13, 1-29.

Kanaya, H. and Ishihara, S. (1973), Regional variation of magnetic susceptibility of the granitic rocks in Japan (in Japanese with English abstract). Jour. Japan. Assoc. Mineral. Petrol. Econ. Geol., 68, 211-224.

Kanisawa, S. (1969), On the Hitokabe granodioritic mass (in Japanese with English abstract). Jous. Japan. Assac. Mineral. Petrol. Econ. Geol., 62, 275-288.

(1972), Coexisting biotites and hornblendes from some granitic rocks in southern Kitakami Mountains, Japan. Jour. Japan. Assoc. Mineral. Petrol. Econ. Geol., 67, 332344.

(1974), Granitic rocks closely associated with the Lower Cretaceous volcanic rocks, Kitakami Mountains, Northeast Japan. Jour. Geol. Soc. Japan, 80, 355-367.
Kato, Y. (1972), Petrology of the Orikabe granitic body, Kitakami Mountainland (in Japanese with English absract). Jour. Japan. Assoc. Mineral. Petrol. Econ. Geol., 67, 50-59.

(1973), Petrology of the Kinkasan granitic body, Kitakami Mountains (in Japanese with English abstract). Jour. Japan. Assoc. Mineral. Petrol. Econ. Geol,, 68, 395-403.

Leake, B.E. (1965), The relationship between composition of calciferous amphibole and grade of metamorphism, 299-318 in Controls of metamorphism, W.S. Pitcher and G.W. Flinn, eds. John Wiley and Sons, Inc. N.Y., $368 \mathrm{pp}$.

(1968), A catalog of analyzed calciferous and subcalciferous amphiboles together with their nomenclature and associated minerals. Geol. Soc. Amer. Spec. Papar, no. 98, 210 pp.

Miyashiro, A. (1961), Evolution of metamorphic belt. Jour. Petrol., 2, 277-311.

Osborn, E.F. (1962), Reaction series for subalkaline igneous rocks based on different oxygen pressure conditions. Amer. Mineral., 47, 211226.

Ryoke Research Group (1972), The mutual relations of the granitic rocks of the Ryoke metamorphic belt in Central Japan (in Japanese with English abstract). Earth Science, 26, 205-216.

Tsusue, A. and Ishihara, S. (1974), The iron titanium oxides in the granitic rcoks of Southwest Japan (in Japanese with English abstract). Mining Geol., 24, 13-30.

Yamada, N. and Nakai, Y. (1969), Geologic relations between the Nohi rhyolites and the socalled Ryoke granites in Central Japan (in Japanese with English abstract). Geol. Soc. Japan, Memoir, no. 4, 51-60.

Yamada, T. (1971), Relation between the Ryoke plutonometamorphism and the late Mesozoic volcanoplutonism in Central Japan (in Japanese with English abstract), Earth Science, 25, 97-104.

中部地方, 領家花峝岩中の角閃石の化学組成

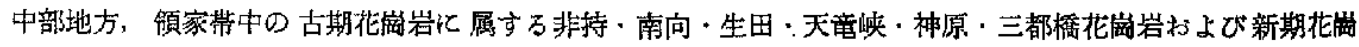

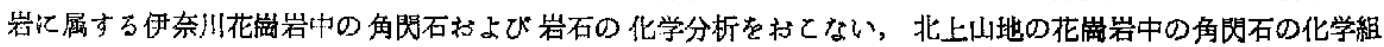

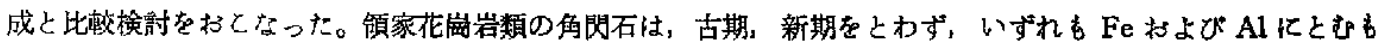

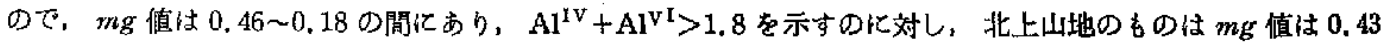




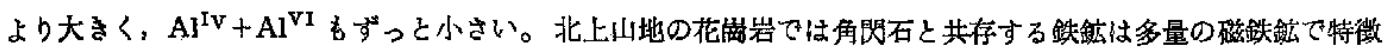
つけられるのに対し，領家带のそれは，一般に，でく少量のチタン鉄鉱と磁硫鉄鉣であるため，角閃石の $\mathrm{Mg}$

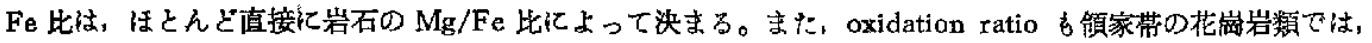
北上山地のもの敕べて，ずっと小さい。との上うな事実は，領家帯の花崗岩類の結晶作用の間の酸䓇分圧が， 北上山地に扔引るをれよりもずっと低かっったととを示しており，両地域の閒の花峛岩生成の条件に大きな差の あったととを暗示する。また，伤閃石中の AI 含量は，結晶作用の閒の圧力のみならず，岩石の総化学成分比支 配されている。

Hiji 非持

Tenryukyo 天竟峡

Inagawa 伊奈川
岩 体 名

Minakata 南向

Kamihara 神原
Ikuta 生田

Mitsuhashi 三都橋 